ISSN 0258-7122

Bangladesh J. Agril. Res. 40(4): 567-580, December 2015

\title{
INFLUENCE OF ETHEPHON ON RIPENING AND QUALITY OF WINTER TOMATO FRUIT HARVESTED AT DIFFERENT MATURITY STAGES
}

\author{
M. MONIRUZZAMAN ${ }^{1}$, R. KHATOON ${ }^{2}$, M. F. B. HOSSAIN ${ }^{3}$ \\ M. T. RAHMAN ${ }^{4}$ AND S. N. ALAM ${ }^{5}$
}

\begin{abstract}
An experiment taking tomato fruits (cv. BARI Tomato-14) of three maturity stages (mature green stage, breaker stage and half ripen stage) and four ethephon levels [control (distilled water spray), 500, 750 and $1000 \mathrm{ppm}$ ] was carried out at the laboratory of plant physiology section of Horticulture research centre, Bangladesh Agricultural Research Institute) during February 14, 2013 to February 27,2012 to find out the suitable stage of fruit maturity for post harvest application of ethephon (ethrel) for tomato ripening. The source of ethrel was Spectrum (ethephon 39\%) manufactured in the United States of America. Treatment with $500-1000 \mathrm{ppm}$ ethephon hastened ripening of tomato by 4 days in mature green stage but by 2 and 4 days in breaker stage tomatoes when compared with control fruits. The highest value of rotting was shown by half ripen tomatoes. The 1000 ppm ethrel gave the maximum rotting irrespective of maturity stages. However, the maximum weight loss and shelf life were found in green mature tomatoes. The shelf life of tomato fruits of green mature and breaker stage tomatoes treated with 500 and $750 \mathrm{ppm}$ was also high. The percentage of rotting and weight loss was increased with gradual advancement of time. The highest value of weight loss and shelf life was recorded in green mature tomatoes without ethephon and with 500 and $750 \mathrm{ppm}$ ethephon treatment. The highest value of vitamin-C, TSS and titrable acidity were shown by half ripen and $\mathrm{pH}$ by green mature tomatoes at different days of storage. The ethephon concentration of $750 \mathrm{ppm}$ the gave maximum vitamin-C at 6 and 9 days of storage but 1000 ppm gave the maximum TSS\% followed by $750 \mathrm{ppm}$ ethephon. The ethephon @ $750 \mathrm{ppm}$ produced the maximum TSS at 9 day of storage in mature green tomatoes but in breaker and half ripen stage tomatoes $750 \mathrm{ppm}$ ethephon gave TSS identical to $1000 \mathrm{ppm}$ at different days of storage. The residue level of ethrel in tomato fruits treated with all ethephon concentrations at 3 and 5 days of storage was below $2 \mathrm{mg} / \mathrm{kg}$ which is safe for human health. Therefore, treated tomatoes should be consumed after 3 days of ethephon application.
\end{abstract}

Keywords: Maturity stage, ethephon (ethrel), ripening, quality, postharvest, tomato.

\section{Introduction}

Tomato (Solanum lycopersicon L.) is one of the most important and popular vegetables in Bangladesh with a considerable total production of 190.2 thousand

\footnotetext{
${ }^{1 \& 4}$ Principal Scientific Officer, HRC, Plant Physiology Section, Bangladesh Agricultural Research Institute (BARI), ${ }^{2 \& 3}$ Scientific Officer, HRC, Plant Physiology section, BARI, ${ }^{5}$ Chief Scientific Officer, Entomology Division, BARI, Bangladesh.
} 
tons produced in an area of 23,828 hectares (BBS, 2011). Tomato is an important horticultural commodity worldwide and plays a key role in the human diet. Tomatoes are rich in flavonoids and other phytochemicals that have anticarcinogenic properties. They are also an excellent source of lutein, zeaxanthin, vitamin $\mathrm{C}$, which is most concentrated in the jelly-like substance that surrounds the seeds, as well as vitamins A, E and B-complex, potassium, manganese and phosphorus.

Proper harvesting at suitable stage determines the nutrient contents as well as storage durability of any fruit. Tomatoes are harvested at different maturity stages, such as green mature stage, breaker stage, half ripen stage and red ripen stage all over the world. Fruits are often harvested at the mature green stage to minimize the damage during post harvest handling. The fruits may later ripen spontaneously or after treatment with ethylene releasing compound (ethephon) before shipment to retailers (Wills and Ku., 2002). Losses often occurred from excessive deterioration during holding and marketing of tomatoes. This problem is especially acute with tomato when harvested at the breaker or more advanced stages of ripeness. Although ripening makes fruit edible and flavourful, it also initiates the gradual deterioration of fruit quality especially in climacteric fruits such as tomato, in which the onset of ripening is considered to be initiated by endogenous ethylene (Abeles et al., 1992). Shelf life is the most important aspect in loss reduction biotechnology of fruits and vegetables. There is a natural tendency for the perishable fruits and vegetables to degrade to the simpler compounds $\left(\mathrm{CO}_{2}, \mathrm{H}_{2} \mathrm{O}\right.$ and $\left.\mathrm{NH}_{3}\right)$ through spontaneous biochemical reaction. This type of reaction reduces the shelf life as well as other qualities of fruits and vegetables. Anju-Kumari et al. (1993) reported that the shelf life for all tomato cultivars were longest with harvesting at the mature green stage (10.9-13.5 days). The acid content is lower in immature fruit and is the highest at the stage when colour starts to appear, with a rapid decrease when the fruit ripens (Cantwell, 1994). During maturation and ripening of fruit there are changes in total soluble solid (TSS). TSS increases from mature green stage to red ripen stages (Helyes et $a l ., 2006)$. The palatability of fruits depends on TSS which increases throughout the development of fruit.

Ethephon or ethrel (2-chloroethylphosphonic acid), an ethylene releasing compound, is known as a plant growth regulator which stimulates ripe evenly fruit, decreasing preservation time and minimizing post-harvest losses (Quoc, et al., 2012). Recently, there have been many mixed opinions on the toxicity of ethephon that confused the customers in Bangladesh. Ethephon has been registered with EPA (US Environmental Protection Agency) since 1973 as a plant growth regulator used to promote fruit ripening and flower induction. Ethephon is irritant to the skin or the eyes but is not a skin sensitizer, it was not a carcinogen and is classified by IARC (International Agency for Research on Cancer) as group D (not carcinogenic to humans) and FAO pointed out a maximum allowable daily intake for ethephon at $0.05 \mathrm{mg} / \mathrm{kg}$ body weight/day 
(Bui, 2007). The recommended residue level of ethephon is $2 \mathrm{mg} / \mathrm{kg}$ of tomato fruit (Anon., 2001). The tomato fruits which are harvested at mature green or breaker stage are treated with different ethephon containing compounds for the colour development and ripening. At present ethephon present in different commercial products viz. Tomtom, Profit and Ripen-15 is being utilized for ripening of immature tomato fruit indiscriminately in high doses $(100 \mathrm{ml} / 5-7$ litre of water for 600-800 kg tomatoes) (BARC, 2012) in Bangladesh. Suitable stages of fruit maturity and optimum doses of ethephon for quality and storage of tomato has not yet been developed for developing countries like Bangladesh. Keeping all above facts in mind, this experiment was conducted to find out the suitable stage of tomato fruit for post harvest application of ethephon and to determine the optimum ethephon dose (s) for tomato ripening without affecting its nutrients.

\section{Materials and Method}

Site: The experimental site was in the physiology laboratory, Horticulture Research Centre, Bangladesh Agricultural Research Institute, Joydebpur, Gazipur. The experiment was conducted during February 14, 2013 to February 27, 2012 at ambient condition. Tomato fruits of different maturity stages were dipped in various concentrations of ethephon (etherl) for five minutes.

Plant material: Freshly harvested tomato fruits of the variety BARI Tomato-14 were collected as per requirement of the study from the vegetable field of HRC, where tomato plants have been grown for this purpose. Tomato fruits were harvested at two maturity stages according to the description by Mitcham et al. (1989): mature green (fully expanded but unripe fruit with mature seed) and breaker (first visible sign of carotenoid accumulation on bottom). Another set of fruits were harvested at half ripen stages $(50 \%$ of the fruit surface are pink coloured) (Moneruzzaman et al. 2008a). After drying in air, each group of fruits was further divided into two parts. One as for the inoculation experiment; the other was directly placed into plastic boxes with approx. $90 \%$ relative humidity $(\mathrm{RH})$, stored at $20^{\circ} \mathrm{C}$, and sampled from fruit pericarp at various time of intervals

Treatment setting: The experiment consisted of three maturity stages $\left(\mathrm{M}_{1}=\right.$ Mature green stage, $\mathrm{M}_{2}=$ breaker stage and $\mathrm{M}_{3}=$ Half- ripen stage) and four levels of ethephon concentrations $\left(T_{1}=\right.$ control , $T_{2}=500 \mathrm{ppm}, \mathrm{T}_{3}=750 \mathrm{ppm}$ and $\mathrm{T}_{4}=1000 \mathrm{ppm}$ ). Fruits were selected based on the uniform size and no physical injuries or infections. Prior to use, fruits were surface-disinfected with $2 \%(\mathrm{v} / \mathrm{v})$ sodium hypochlorite for $2 \mathrm{~min}$, rinsed with tap water, and air-dried. Then, fruits at each stage were immersed in different solutions for $5 \mathrm{~min}$. Ten tomato fruits weighing $1000 \mathrm{~g}$ were placed for each treatment. The experiment was laid out in CRD with three replications. The source of ethephon was Spectrum (Ethephon 39\%) manufactured in the United States of America. The temperature and relative humidity was $23.5^{\circ} \mathrm{c} \pm 1.5^{\circ} \mathrm{C}$ and $65-70 \%$, respectively in the laboratory. 
Parameter studied: The parameters studied were days required for ripening, shelf life, weight loss (\%), rotting (\%), vitamin-C in tomato pulp, $\mathrm{pH}$ of tomato juice, total titrable acidity content, TSS content of tomato pulp. Each data was recorded at 3 days interval upto 9 days but rotting (\%) and shelf life was observed up to 11 and 14 days.

Days required for ripening: In order to determine days required for ripening, tomatoes were daily observed for their colour and the time (days) required to reach light red stage, between 60 and $90 \%$ fully red ripe stage (that is red colour of tomato surface between 60 and $90 \%$ ) was measured.

Shelf life: The shelf life was calculated by counting the days required to attain the last stage of ripening but up to the stage when fruit remained still acceptable for marketing.

Weight loss: The weight loss of tomato fruit sample was calculated by using the following formula:

Total weight loss of fruit $(\%)=\frac{\text { Initial weight }- \text { Final weight }}{\text { Initial weight }} \times 100$

Rotting (\%): Rotting was determined by visual observation. Unmarketable tomatoes including fruits with various spots developed on the peel, rotten, decayed and shriveled fruits were considered as rotten.

Vitamin-C content of tomato pulp: Vitamin-C in tomato pulp was estimated by 2,6-Dichlorophenol-indophenol visual titration method as described by Rangana (1986). The reagents used for the estimation of vitamin-C were as follows: 1) Metaphosphoric acid (6\%), 2) standard ascorbic acid solution, 3) 2-6 dichlorophenolindophenol dye. For estimation of vitamin-C, the following steps were followed: Standardization of dye solution, preparation of solution and titration.

Vitamin-C content $($ mg per $100 \mathrm{~g}$ of fruit pulp $)=\frac{\mathrm{T} \times \mathrm{D} \times \mathrm{V} 1 \times 100}{\mathrm{~V} 2 \times \mathrm{W}}$

Where, $T=$ Titre, $D=$ Dye factor, $V_{1}=$ Volume made up, $V_{2}=$ Volume of extract taken for estimation and $w=$ weight of sample taken for estimation

Total titrable acidity content of tomato pulp: Total titrable acidity was determined using the following steps (Rangana, 1986): At first sample blended, filtered, transferred to volumetric flax and volume made up to the mark. Ttitrated with $0.10 .1 \mathrm{~N} \mathrm{NaOH}$. Percentage of titrable acidity was calculated using the following formula:

Total titrable acidity $(\%)=\frac{\mathrm{T} \times \mathrm{N} \times \mathrm{E} \times \mathrm{V} 1 \times 100}{\mathrm{~V} 2 \times \mathrm{W}}$

Where, $T=$ Titre, $N=$ normality of $\mathrm{NaOH}, V_{l}=$ Volume made up, $E=$ Equivalent weight of acid $V_{2}=$ Volume of extract taken for estimation and $w=$ weight of sample taken for estimation. 
pH of tomato juice: The sample for $\mathrm{pH}$ determination was prepared by the method described by Rangana (1986). One gram of sample was homogenized in $1 \mathrm{ml}$ of boiled distilled water and $1 \mathrm{ml}$ of de-ionized water of $\mathrm{pH} 7.0$ and the $\mathrm{pH}$ of tomato juice was recorded by an electronic $\mathrm{pH}$ meter. The $\mathrm{pH}$ meter was standardized with the help of buffer solution.

TSS content of tomato pulp: Total Soluble Solid (TSS) content of tomato fruit pulp was determined by using Digital Hand Refractometer by placing a drop of pulp solution on its prism. The percentage of TSS was obtained from the direct reading of the refractometer.

Residue level of ethephon: Residue level of ethephon in ethrel (0-1000 ppm) treated tomatoes of green mature stage was measured by Gas Chromatography flame-ionized detector in Toxicology laboratory, Entomology Division, Bangladesh Agricultural Research Institute (Rahman et al., 2012). Extra treatment (tomatoes treated with $2000 \mathrm{ppm}$ ethrel) was also analyzed for clear understanding although this treatment was not included in this experiment.

The data collected were subjected to an analysis of variance using MSTAT-C. Mean separation was performed by DMRT at 5\% level of probability.

\section{Results and Discussion}

\section{Days required for ripening}

The mature green tomatoes took about 6 days to reach the full ripening stage whereas breaker stage tomatoes took 5 days and half ripen tomatoes 4 days (Table 1). The ethephon hastened ripening of tomatoes compared to control (Table 1). The 500, 750 and $1000 \mathrm{ppm}$ ethephon hastened tomato ripening by 2 , 3 and 4 days compared to control. In mature green tomatoes, $500 \mathrm{ppm}$ ethephon accelerated ripening by 4 days while 750 and 1000 ppm ethephon accelerated ripening by 6 days (Table 2). But in breaker stage tomatoes 500 and 700 ppm ethephon accelerated ripening by 2 days and 1000 ppm by 3 days. In case of half ripen tomatoes $500 \mathrm{ppm}$ ethephon hastened ripening by 2 days while 750 and 1000 ppm by 3 days. Moura et al. (1997) found 1000 ppm ethephon solution was more efficient in hastening tomato ripening. It was found by Olympio and Norman (2000) that concentrations of 500 and $1000 \mathrm{ppm}$ ethephon reduced the ripening time. The mango cultivars treated with $0.8 \%(8000 \mathrm{ppm})$ ethephon accelerated ripening (Thanh Hai, et al., 2009).

\section{Shelf life of tomato}

Mature green tomato had a higher storability than the breaker stage followed by half ripen tomatoes (Table 1). Maximum shelf life was 11.3 days in mature green tomatoes followed by breaker stage ( 8.6 days) and minimum was 7.6 days for half ripen tomatoes. It was found by Moneruzzaman et al. (2008a) that mature green tomatoes of cv. Roma VF had the highest shelf life (13 days) followed by 
half ripen tomato (12 days). Ethephon levels had also significant effect on shelf life of tomatoes (Table 1). Control was recorded to give the longest shelf life (10.22 days), followed by $500 \mathrm{ppm}$ (9.33 days) and $750 \mathrm{ppm}$ (9.00 days). The lowest shelf life was recorded by $1000 \mathrm{ppm}$ ethephon (8.00 days). After penetration into cell ethephon might cause damage to some tissues that helps in rotting of fruits and thus reduced the shelf life (Anon., 2010).

Table 1. Main effect of maturity stage and ethephon on days required for ripening and shelf life of treated tomato (var. BARI Tomato-14).

\begin{tabular}{l|c|c}
\hline Treatment & $\begin{array}{c}\text { Days required for } \\
\text { ripening }\end{array}$ & Shelf life (days) \\
\hline Maturity stages & $5.9 \mathrm{a}$ & $11.3 \mathrm{a}$ \\
Mature green stage $\left(\mathrm{M}_{1}\right)$ & $5.0 \mathrm{~b}$ & $8.6 \mathrm{~b}$ \\
Breaker stage $\left(\mathrm{M}_{2}\right)$ & $4.0 \mathrm{c}$ & $7.6 \mathrm{c}$ \\
Half ripen stage $\left(\mathrm{M}_{3}\right)$ & & \\
Ethephon concentration & $7.4 \mathrm{a}$ & $10.22 \mathrm{a}$ \\
Control (distilled water) $\left(\mathrm{T}_{1}\right)$ & $5.1 \mathrm{~b}$ & $9.33 \mathrm{~b}$ \\
$500 \mathrm{ppm}\left(\mathrm{T}_{2}\right)$ & $4.1 \mathrm{c}$ & $9.00 \mathrm{~b}$ \\
$750 \mathrm{ppm}\left(\mathrm{T}_{3}\right.$ & $3.2 \mathrm{~d}$ & $8.00 \mathrm{c}$ \\
$1000 \mathrm{ppm}\left(\mathrm{T}_{4}\right)$ & 8.87 & 6.32 \\
\hline $\mathrm{CV}(\%)$ &
\end{tabular}

Means within a column having different letters are significantly different at $5 \%$ level by DMRT.

Table 2. Combined effect of maturity stages and ethephon on days required for ripening and shelf life of tomato (var. BARI Tomato-14).

\begin{tabular}{c|c|c|c}
\hline \multicolumn{2}{c|}{ Treatment } & Shelf life (days) \\
\cline { 1 - 2 } Maturity stage & $\begin{array}{c}\text { Ethephon } \\
\text { conc. }\end{array}$ & Days required for ripening & \\
\hline \multirow{3}{*}{$\mathrm{M}_{1}$} & $\mathrm{~T}_{1}$ & $9.7 \mathrm{a}$ & $12.3 \mathrm{a}$ \\
& $\mathrm{T}_{2}$ & $6.0 \mathrm{c}$ & $11.3 \mathrm{a}$ \\
& $\mathrm{T}_{3}$ & $4.3 \mathrm{ef}$ & $11.3 \mathrm{a}$ \\
& $\mathrm{T}_{4}$ & $3.7 \mathrm{fgh}$ & $10.0 \mathrm{~b}$ \\
$\mathrm{M}_{2}$ & $\mathrm{~T}_{1}$ & $7.0 \mathrm{~b}$ & $9.3 \mathrm{bc}$ \\
& $\mathrm{T}_{2}$ & $5.3 \mathrm{~cd}$ & $8.3 \mathrm{~cd}$ \\
& $\mathrm{~T}_{3}$ & $4.7 \mathrm{de}$ & $9.00 \mathrm{bcd}$ \\
& $\mathrm{T}_{4}$ & $3.0 \mathrm{~h}$ & $7.7 \mathrm{de}$ \\
$\mathrm{M}_{3}$ & $\mathrm{~T}_{1}$ & $5.7 \mathrm{c}$ & $9.0 \mathrm{bcd}$ \\
& $\mathrm{T}_{2}$ & $4.0 \mathrm{efg}$ & $8.3 \mathrm{~cd}$ \\
& $\mathrm{~T}_{3}$ & $3.3 \mathrm{gh}$ & $6.7 \mathrm{ef}$ \\
$\mathrm{CV}(\%)$ & $\mathrm{T}_{4}$ & $3.0 \mathrm{~h}$ & $6.3 \mathrm{f}$ \\
\hline
\end{tabular}

Means within a column having different letters are significantly different at $5 \%$ level by DMRT, $M_{1}=$ Mature green stage, $M_{2}=$ Breaker stage, $M_{3}=$ Half ripen stage, $T_{1}=$ Control (distilled water), $\mathrm{T}_{2}=500 \mathrm{ppm}, \mathrm{T}_{3}=750 \mathrm{ppm}, \mathrm{T}_{6}=1000 \mathrm{ppm}$. 
The maximum shelf life (12.3 days) was recorded in case of mature green tomatoes without ethephon application (Table 2). The lowest shelf life was found from $1000 \mathrm{ppm}$ ethephon applied in half ripen tomatoes (6.3 days) closely followed by $750 \mathrm{ppm}$ ethephon (6.7 days) applied in the same stage tomatoes. The ethephon level of 500 and $750 \mathrm{ppm}$ coupled with mature green tomatoes gave shelf life identical to green mature tomatoes treated with distilled water (control). Similar results were given by 500 and $750 \mathrm{ppm}$ ethephon in breaker stage tomatoes. The ethephon level of $500 \mathrm{ppm}$ coupled with half ripen tomatoes gave shelf life identical to same stage tomatoes treated with distilled water (control).

Table 3. Main effect of maturity stages and ethephon on weight loss and rotting of tomato at different days of storage.

\begin{tabular}{|c|c|c|c|c|c|c|c|c|c|}
\hline \multicolumn{10}{|c|}{ Duration of storage } \\
\hline \multirow{2}{*}{ Treatment } & \multicolumn{4}{|c|}{ Weight loss (\%) } & \multicolumn{5}{|c|}{ Rotting (\%) } \\
\hline & OD & $3 \mathrm{D}$ & $6 \mathrm{D}$ & $9 \mathrm{D}$ & OD & $3 \mathrm{D}$ & $6 \mathrm{D}$ & $9 \mathrm{D}$ & $11 \mathrm{D}$ \\
\hline \multicolumn{10}{|c|}{ Stage of maturity } \\
\hline $\mathrm{M}_{1}$ & 0.00 & $3.52 \mathrm{a}$ & $5.25 \mathrm{a}$ & $7.64 \mathrm{a}$ & 0.00 & 0.00 & $0.00 \mathrm{c}$ & $6.67 \mathrm{c}$ & $8.33 c$ \\
\hline $\mathrm{M}_{2}$ & 0.00 & $2.93 \mathrm{~b}$ & $4.35 b$ & $6.04 b$ & 0.00 & 0.00 & $2.23 b$ & $23.17 b$ & $35.83 b$ \\
\hline $\mathrm{M}_{3}$ & 0.00 & $2.65 \mathrm{c}$ & $4.02 \mathrm{~b}$ & $5.90 \mathrm{~b}$ & 0.00 & 0.00 & $5.83 \mathrm{a}$ & $30.83 a$ & $50.83 a$ \\
\hline \multicolumn{10}{|c|}{ Ethephon Conc. } \\
\hline $\mathrm{T}_{1}$ & 0.00 & $2.31 \mathrm{c}$ & $3.82 b$ & $5.16 c$ & 0.00 & 0.00 & $0.00 \mathrm{c}$ & $2.22 \mathrm{c}$ & $2.22 \mathrm{~d}$ \\
\hline $\mathrm{T}_{2}$ & 0.00 & $2.78 b$ & $3.49 \mathrm{~b}$ & $5.12 \mathrm{c}$ & 0.00 & 0.00 & $0.00 \mathrm{c}$ & $15.56 \mathrm{~b}$ & $22.22 \mathrm{c}$ \\
\hline $\mathrm{T}_{3}$ & 0.00 & $3.48 \mathrm{a}$ & $5.26 \mathrm{a}$ & $7.77 b$ & 0.00 & 0.00 & $5.56 \mathrm{~b}$ & $32.22 \mathrm{a}$ & $45.56 \mathrm{~b}$ \\
\hline $\mathrm{T}_{4}$ & 0.00 & $3.56 \mathrm{a}$ & $5.60 \mathrm{a}$ & $8.54 \mathrm{a}$ & 0.00 & 0.00 & $11.11 \mathrm{a}$ & $30.22 \mathrm{a}$ & $56.67 \mathrm{a}$ \\
\hline $\mathrm{CV}(\%)$ & & 7.23 & 7.68 & 7.09 & & & 11.58 & 13.56 & 13.39 \\
\hline
\end{tabular}

Means within a column having different letters are significantly different at $5 \%$ level by DMRT, $M_{1}=$ Mature green stage, $M_{2}=$ Breaker stage, $M_{3}=$ Half ripen stage, $\mathrm{T}_{1}=$ Control Control (distilled water), $\mathrm{T}_{2}=500 \mathrm{ppm}, \mathrm{T}_{3}=750 \mathrm{ppm}, \mathrm{T}_{6}=1000 \mathrm{ppm}, \mathrm{D}=$ Day.

\section{Weight loss (\%)}

Maturity stages, ethephon levels and their combination were found to have significant effect on total loss in weight of fruit (Tables 3 and 4). Total weight loss in mature green tomatoes was always higher during the entire period of storage. At the third day of storage, it was $3.52 \%$ that rose to $7.64 \%$ at $9^{\text {th }}$ day. In half ripen tomatoes, weight loss was the lowest, being $2.65 \%$ at $3^{\text {rd }}$ day and $5.90 \%$ at $9^{\text {th }}$ day of storage. Weight loss in mature green tomatoes was higher because of higher rate of dehydration that generally happened in tender tissue. This is in line with the result of Moneruzzaman et al. (2008a). Ethephon solution also had significant effect on weight loss of tomato (Table 3). The ethephon solution of 750 and $1000 \mathrm{ppm}$ gave higher weight loss than other treatments at 3 and 6 day of storage. Ethephon 1000 ppm gave the highest weight loss at 9 day 
of storage. The ethephon level of $500 \mathrm{ppm}$ produced higher weight loss than control at 3 day of storage but this level gave weight loss identical to control at 6 and 9 day of storage. The interaction effect was significant at 3,6 and 9 day of storage with regard to total weight loss in fruit (Table 4). Here the weight loss gradually increased with the advancement of storage period. Ethephon at 750 and $1000 \mathrm{ppm}$ at the $3^{\text {rd }}$ and $6^{\text {th }}$ day of storage and $1000 \mathrm{ppm}$ at 9 day of storage gave maximum weight loss in green mature tomatoes. The half ripen tomatoes coupled with control gave minimum weight loss at all days of storage. It was also found by Quoc et al. (2012) that during post harvest ripening, weight loss rate in acerolas fruit treated with ethephon increased over the preservation time.

\section{Rotting (\%)}

Stages of maturity, ethephon levels, and their combinations were found to have significant effect on rotting (\%) of tomatoes (Tables $3 \& 4$ ). Rotting in half ripen tomatoes was found always higher during the entire period of storage. There were no rotten tomatoes found at $3^{\text {rd }}$ day in all maturity stages. The green mature tomatoes also did not get rotten at 6 day of storage. At the $6^{\text {th }}$ day of storage total rotting percent was $5.83 \%$ that rose to $50.83 \%$ on 9 day of storage in half ripen tomatoes (Table 3). On the other hand rotting percent in mature green tomatoes being $6.67 \%$ at $9^{\text {th }}$ day and was $8.33 \%$ at 11 day of storage. In breaker stage the rotting percent was $2.23 \%$ at 6 day, $23.17 \%$ at 9 day that rose to $35.83 \%$ at 11 day of storage. The rotting percent was higher in half ripen tomatoes because of higher rate of transpiration, more skin permeability for water loss and high susceptibility to decay organism of this climacteric type of fruit. This corroborates the report of Moneruzzaman et al. (2008a). The highest rotting of $11.11 \%$ was recorded in $1000 \mathrm{ppm}$ ethephon at 6 day of storage. But at 9 day of storage the maximum rotting \% was noticed in $750 \mathrm{ppm}$ and $1000 \mathrm{ppm}$ ethephon. Again at 11 day of storage rotting $\%$ was found highest in 1000 ppm ethephon. The ethephon level of $1000 \mathrm{ppm}$ gave the highest rotting percent irrespective of maturity at 6 day of storage (Table 5). The ethephon 500 and $750 \mathrm{ppm}$ did not show any rotting at 6 day of storage. The ethephon solution of $750 \mathrm{ppm}$ gave no rotting at 6 days storage. At 9 day of storage there was no significant difference between 750 and $1000 \mathrm{ppm}$ ethephon irrespective of maturity stages. The highest rotting percent was recorded from $1000 \mathrm{ppm}$ ethephon in half ripen tomatoes closely followed by same ethephon solution in breaker stage tomatoes and $750 \mathrm{ppm}$ ethrel in half ripen tomatoes at 11 day of storage. This is perfect agreement with the results of Dhall and singh (2013) who reported that rotting percentage of green mature tomatoes increased with increase in the concentration of ethephon (500-1500 ppm) and with the duration of days for which the fruits were kept for ripening. The green mature and breaker stage tomatoes gave no rotting when no ethephon was applied. 
Table 4. Combined effect of maturity stages and ethephon on weight loss of tomato (cv.BARI Tomato-14) fruit during storage.

\begin{tabular}{|c|c|c|c|c|c|}
\hline \multicolumn{6}{|c|}{ Days after storage } \\
\hline \multicolumn{2}{|c|}{ Treatment } & \multirow[b]{2}{*}{ OD } & \multirow[b]{2}{*}{$3 \mathrm{D}$} & \multirow[b]{2}{*}{$6 \mathrm{D}$} & \multirow[b]{2}{*}{ 9D } \\
\hline $\begin{array}{l}\text { Maturity } \\
\text { stages }\end{array}$ & $\begin{array}{l}\text { Ethephon } \\
\text { conc. }\end{array}$ & & & & \\
\hline \multirow{4}{*}{$\mathrm{M}_{1}$} & $\mathrm{~T}_{1}$ & 0.00 & $2.68 \mathrm{~cd}$ & $4.40 \mathrm{de}$ & $5.93 \mathrm{e}$ \\
\hline & $\mathrm{T}_{2}$ & 0.00 & $3.21 \mathrm{bc}$ & $3.92 \mathrm{ef}$ & $5.71 \mathrm{e}$ \\
\hline & $\mathrm{T}_{3}$ & 0.00 & $4.01 \mathrm{a}$ & $6.18 \mathrm{a}$ & $9.02 b$ \\
\hline & $\mathrm{T}_{4}$ & 0.00 & $4.17 \mathrm{a}$ & $6.51 \mathrm{a}$ & $9.90 \mathrm{a}$ \\
\hline \multirow{4}{*}{$\mathrm{M}_{2}$} & $\mathrm{~T}_{1}$ & 0.00 & $2.25 \mathrm{de}$ & $4.74 f g$ & $5.04 f$ \\
\hline & $\mathrm{T}_{2}$ & 0.00 & $2.72 \mathrm{~cd}$ & $3.4 \mathrm{gh}$ & $5.00 \mathrm{f}$ \\
\hline & $\mathrm{T}_{3}$ & 0.00 & $4.40 \mathrm{~b}$ & $5.03 \mathrm{bc}$ & $7.54 \mathrm{c}$ \\
\hline & $\mathrm{T}_{4}$ & 0.00 & $3.37 b$ & $5.25 \mathrm{~b}$ & $8.03 \mathrm{c}$ \\
\hline \multirow{4}{*}{$\mathrm{M}_{3}$} & $\mathrm{~T}_{1}$ & 0.00 & $2.00 \mathrm{e}$ & $3.34 \mathrm{gh}$ & $4.50 f$ \\
\hline & $\mathrm{T}_{2}$ & 0.00 & $2.42 \mathrm{de}$ & $3.17 \mathrm{~h}$ & $4.65 f$ \\
\hline & $\mathrm{T}_{3}$ & 0.00 & $3.02 \mathrm{bc}$ & $4.56 \mathrm{~cd}$ & $6.75 d$ \\
\hline & $\mathrm{T}_{4}$ & 0.00 & $3.15 \mathrm{bc}$ & $5.03 \mathrm{bc}$ & $7.70 \mathrm{c}$ \\
\hline $\mathrm{CV}(\%)$ & & & 7.23 & 7.68 & 7.09 \\
\hline
\end{tabular}

Means within a column having different letters are significantly different at $5 \%$ level by DMRT, $M_{1}=$ Mature green stage, $M_{2}=$ Breaker stage, $M_{3}=$ Half ripen stage, $T_{1}=$ Control (distilled water), $\mathrm{T}_{2}=500 \mathrm{ppm}, \mathrm{T}_{3}=750 \mathrm{ppm}, \mathrm{T}_{6}=1000 \mathrm{ppm} ; \mathrm{D}=$ Day.

Table 5. Combined effect of and maturity stages and ethephon on rotting of tomato (cv.BARI Tomato-14) fruits during storage.

\begin{tabular}{|c|c|c|c|c|c|c|}
\hline \multicolumn{7}{|c|}{ Days after storage } \\
\hline \multicolumn{2}{|c|}{ Treatment } & \multirow[b]{2}{*}{ OD } & \multirow[b]{2}{*}{$3 \mathrm{D}$} & \multirow[b]{2}{*}{$6 \mathrm{D}$} & \multirow[b]{2}{*}{$9 \mathrm{D}$} & \multirow[b]{2}{*}{$11 \mathrm{D}$} \\
\hline $\begin{array}{l}\text { Maturity } \\
\text { stages }\end{array}$ & $\begin{array}{l}\text { Ethephon } \\
\text { conc. }\end{array}$ & & & & & \\
\hline \multirow{5}{*}{$\mathrm{M}_{1}$} & $\mathrm{~T}_{1}$ & 0.00 & 0.00 & $0.00 \mathrm{~d}$ & $0.00 \mathrm{e}$ & $0.00 \mathrm{~d}$ \\
\hline & $\mathrm{T}_{2}$ & 0.00 & 0.00 & $0.00 \mathrm{~d}$ & $10.00 \mathrm{~d}$ & $10.00 \mathrm{c}$ \\
\hline & $\mathrm{T}_{3}$ & 0.00 & 0.00 & $0.00 \mathrm{~d}$ & $10.00 \mathrm{~d}$ & $10.00 \mathrm{c}$ \\
\hline & $\mathrm{T}_{4}$ & 0.00 & 0.00 & $6.68 c$ & $6.68 d$ & $6.68 \mathrm{~cd}$ \\
\hline & $\mathrm{T}_{1}$ & 0.00 & 0.00 & $0.00 \mathrm{~d}$ & $0.00 \mathrm{e}$ & $0.00 \mathrm{~d}$ \\
\hline \multirow{3}{*}{$\mathrm{M}_{2}$} & $\mathrm{~T}_{2}$ & 0.00 & 0.00 & $0.00 \mathrm{~d}$ & $13.34 d$ & $13.33 \mathrm{bcd}$ \\
\hline & $\mathrm{T}_{3}$ & 0.00 & 0.00 & $6.68 c$ & $36.67 \mathrm{ab}$ & $53.33 \mathrm{ab}$ \\
\hline & $\mathrm{T}_{4}$ & 0.00 & 0.00 & $13.33 \mathrm{a}$ & $36.67 \mathrm{ab}$ & $76.67 \mathrm{a}$ \\
\hline \multirow{4}{*}{$\mathrm{M}_{3}$} & $\mathrm{~T}_{1}$ & 0.00 & 0.00 & $0.00 \mathrm{~d}$ & $6.68 d$ & $6.68 \mathrm{~d}$ \\
\hline & $\mathrm{T}_{2}$ & 0.00 & 0.00 & $0.00 \mathrm{~d}$ & $23.34 \mathrm{bc}$ & $36.67 \mathrm{bcd}$ \\
\hline & $\mathrm{T}_{3}$ & 0.00 & 0.00 & $10.00 \mathrm{~b}$ & $50.00 \mathrm{a}$ & $73.33 \mathrm{a}$ \\
\hline & $\mathrm{T}_{4}$ & 0.00 & 0.00 & $13.33 \mathrm{a}$ & $47.33 \mathrm{a}$ & $86.67 \mathrm{a}$ \\
\hline $\mathrm{CV}(\%)$ & & & & 11.58 & 13.56 & 13.39 \\
\hline
\end{tabular}

Means within a column having different letters are significantly different at $5 \%$ level by DMRT, $\mathrm{M}_{1}=$ Mature green stage, $\mathrm{M}_{2}=$ Breaker stage, $\mathrm{M}_{3}=$ Half ripen stage, $\mathrm{T}_{1}=$ Control Control (distilled water), $\mathrm{T}_{2}=500 \mathrm{ppm}, \mathrm{T}_{3}=750 \mathrm{ppm}, \mathrm{T}_{6}=1000 \mathrm{ppm} ; \mathrm{D}=$ day. 


\section{Vitamin-C content of tomato pulp}

Vitamin-C content of tomato pulp varied significantly in fruits of different maturity (Table 6). Results showed that vitamin-C content was decreased with the advancement of time. Half ripen tomato contained the highest quantity of vitamin-C $(18.10 \mathrm{mg} / 100 \mathrm{~g})$ while the mature green tomato contained the lowest quantity of vitamin-C $(11.43 \mathrm{mg} / 100 \mathrm{~g})$ at harvest. This is perfect agreement with Moneruzzaman et al. (2008b). At 6 and 9 day of storage ethephon treatment with all concentrations maintained a lead over control in respect of vitamin-C content. This in agreement with Thanh Hai, et al. (2009) who got the maximum Vitamin$\mathrm{C}$ content in mango compared to control using $0.8 \%$ (8000 ppm) ethephon. The $1000 \mathrm{ppm}$ ethephon gave the highest vitamin-C at 6 day of storage whereas 750 ppm ethephon gave the maximum at 9 day of storage. Maturity stages, ethephon and their combinations were found to have significant effect (Table 7). The maximum vitamin-C content at $6^{\text {th }}$ and $9^{\text {th }}$ day of storage was recorded in half ripen tomato coupled with 1000ppm ethephon which was statistically similar to $1000 \mathrm{ppm}$ ethephon coupled with the same maturity. In mature green and breaker stage tomatoes $1000 \mathrm{ppm}$ ethephon produced the maximum vit.-C.

Table 6. Main effect of maturity stages and ethephon on vitamin $-\mathrm{C}$ and $\mathrm{pH}$ content of tomato (cv. BARI Tomato-14) at different days of storage.

\begin{tabular}{l|ccccc|c|c|c|}
\hline \multicolumn{8}{c}{ Duration of storage } \\
\hline \multirow{2}{*}{ Treatment } & \multicolumn{9}{c}{ Vitamin-C (mg/100g) } & \multicolumn{3}{c}{$\mathrm{pH}$} \\
\cline { 2 - 9 } & 0D & $3 \mathrm{D}$ & $6 \mathrm{D}$ & $9 \mathrm{D}$ & $0 \mathrm{D}$ & $3 \mathrm{D}$ & $6 \mathrm{D}$ & $9 \mathrm{D}$ \\
\hline Maturity stages & & & & & & & \\
$\mathrm{M}_{1}$ & $11.43 \mathrm{c}$ & $10.34 \mathrm{c}$ & $10.25 \mathrm{c}$ & $7.51 \mathrm{c}$ & $4.12 \mathrm{a}$ & 4.14 & $4.18 \mathrm{a}$ & $4.22 \mathrm{a}$ \\
$\mathrm{M}_{2}$ & $14.26 \mathrm{~b}$ & $12.93 \mathrm{~b}$ & $13.20 \mathrm{~b}$ & $11.75 \mathrm{~b}$ & $4.09 \mathrm{~b}$ & 4.10 & $4.13 \mathrm{ab}$ & $4.18 \mathrm{~b}$ \\
$\mathrm{M}_{3}$ & $18.10 \mathrm{a}$ & $16.45 \mathrm{a}$ & $16.93 \mathrm{a}$ & $14.54 \mathrm{a}$ & $4.04 \mathrm{c}$ & 4.06 & $4.09 \mathrm{~b}$ & $4.14 \mathrm{c}$ \\
Ethephon conc. & & & & & & & \\
$\mathrm{T}_{1}$ & 14.56 & $14.38 \mathrm{a}$ & $12.87 \mathrm{~d}$ & $11.02 \mathrm{c}$ & 4.08 & 4.09 & 4.14 & 4.18 \\
$\mathrm{~T}_{2}$ & 14.60 & $13.00 \mathrm{~b}$ & $13.43 \mathrm{c}$ & $10.81 \mathrm{c}$ & 4.09 & 4.12 & 4.13 & 4.17 \\
$\mathrm{~T}_{3}$ & 14.60 & $13.82 \mathrm{~b}$ & $13.67 \mathrm{~b}$ & $11.88 \mathrm{a}$ & 4.08 & 4.10 & 4.13 & 4.18 \\
$\mathrm{~T}_{4}$ & 14.62 & $12.76 \mathrm{~b}$ & $13.87 \mathrm{a}$ & $11.36 \mathrm{~b}$ & 4.09 & 4.10 & 4.13 & 4.19 \\
\hline $\mathrm{CV}(\%)$ & 3.74 & 4.73 & 3.52 & 3.87 & 4.06 & 3.17 & 4.05 & 2.74 \\
\hline
\end{tabular}

Means within a column having different letters are significantly different at $5 \%$ level by DMRT, $\mathbf{M}_{1}=$ Mature green, $\mathrm{M}_{2}=$ Breaker stage, $\mathrm{M}_{3}=$ Half ripen stage, $\mathrm{T}_{1}=$ Control (distilled water), $\mathrm{T}_{2}=500 \mathrm{ppm}, \mathrm{T}_{3}=750 \mathrm{ppm}, \mathrm{T}_{6}=1000 \mathrm{ppm} ; \mathrm{D}=\mathrm{Day}$.

\section{pH of tomato juice}

The $\mathrm{pH}$ content of tomato juice varied significantly in fruits of different maturity (Table 6). It was found that $\mathrm{pH}$ increased with the advancement of ripening of fruit. Matsumoto et al. (1983) declared that organic acids are metabolized by the fruit during ripening and storage. During entire period of storage the highest $\mathrm{pH}$ value was observed in mature green tomatoes followed by breaker stage and half ripen fruit, respectively. This result corroborates the results of Moneruzzaman et al. (2008b). The effects of ethephon on $\mathrm{pH}$ of tomato were not found significant during storage. The interaction effect on $\mathrm{pH}$ was also insignificant. 
Table 7. Combined effect of maturity stages and ethephon on vitamin-C content of tomato (cv. BARI Tomato-14 ) fruits during storage.

\begin{tabular}{|c|c|c|c|c|c|}
\hline \multicolumn{6}{|c|}{ Duration of storage } \\
\hline \multicolumn{2}{|c|}{ Treatment } & \multirow[b]{2}{*}{ OD } & \multirow[b]{2}{*}{ 3D } & \multirow[b]{2}{*}{$6 \mathrm{D}$} & \multirow[b]{2}{*}{ 9D } \\
\hline $\begin{array}{l}\text { Maturity } \\
\text { stages }\end{array}$ & Ethrel conc. & & & & \\
\hline \multirow{4}{*}{$\mathrm{M}_{1}$} & $\mathrm{~T}_{1}$ & 11.41 & 11.38 & $10.04 \mathrm{~g}$ & $7.45 \mathrm{~g}$ \\
\hline & $\mathrm{T}_{2}$ & 11.47 & 10.15 & $10.14 \mathrm{f}$ & $7.82 \mathrm{~g}$ \\
\hline & $\mathrm{T}_{3}$ & 11.41 & 9.45 & $10.35 f$ & $7.87 \mathrm{~g}$ \\
\hline & $\mathrm{T}_{4}$ & 11.43 & 9.88 & $10.47 \mathrm{f}$ & $6.91 \mathrm{~h}$ \\
\hline \multirow{4}{*}{$\mathrm{M}_{2}$} & $\mathrm{~T}_{1}$ & 14.20 & 14.15 & $12.54 \mathrm{~d}$ & $11.16 \mathrm{f}$ \\
\hline & $\mathrm{T}_{2}$ & 14.25 & 12.68 & $12.52 \mathrm{~d}$ & $11.79 \mathrm{e}$ \\
\hline & $\mathrm{T}_{3}$ & 14.29 & 12.40 & $12.40 \mathrm{e}$ & $12.32 \mathrm{~d}$ \\
\hline & $\mathrm{T}_{4}$ & 14.29 & 12.50 & $12.48 \mathrm{e}$ & $11.73 \mathrm{e}$ \\
\hline \multirow{4}{*}{$\mathrm{M}_{3}$} & $\mathrm{~T}_{1}$ & 18.06 & 17.61 & $16.04 b$ & $14.44 \mathrm{~b}$ \\
\hline & $\mathrm{T}_{2}$ & 18.08 & 16.18 & $13.12 \mathrm{c}$ & $12.82 \mathrm{c}$ \\
\hline & $\mathrm{T}_{3}$ & 18.10 & 16.12 & $16.09 \mathrm{~b}$ & $15.45 \mathrm{a}$ \\
\hline & $\mathrm{T}_{4}$ & 18.15 & 16.89 & $16.46 \mathrm{a}$ & $15.45 \mathrm{a}$ \\
\hline CV $(\%)$ & & 3.74 & 4.73 & 3.52 & 3.87 \\
\hline
\end{tabular}

Means within a column having different letters are significantly different at 5\% level by DMRT, $M_{1}=$ Mature green stage, $M_{2}=$ Breaker stage, $M_{3}=$ Half ripen stage, $T_{1}=$ Control (distilled water), $\mathrm{T}_{2}=500 \mathrm{ppm}, \mathrm{T}_{3}=750 \mathrm{ppm}, \mathrm{T}_{6}=1000 \mathrm{ppm} ; \mathrm{D}=\mathrm{Day}$.

Table 8. Main effect of maturity stages and ethrel and on TSS and titrable acidity content of tomato (cv. BARI Tomato-14) at different days of storage.

\begin{tabular}{l|ccc|c|c|c|c|c}
\hline \multicolumn{10}{c}{ TSS } & \multicolumn{7}{c}{ Titrable acidity } \\
\hline \multirow{2}{*}{ Treatment } & $0 \mathrm{D}$ & $3 \mathrm{D}$ & $6 \mathrm{D}$ & $9 \mathrm{D}$ & $0 \mathrm{D}$ & $3 \mathrm{D}$ & $6 \mathrm{D}$ & $9 \mathrm{D}$ \\
\cline { 2 - 9 } & \multicolumn{1}{c}{ Maturity stages } & & & & & & & \\
$\mathrm{M}_{1}$ & $3.83 \mathrm{c}$ & $4.20 \mathrm{c}$ & $4.21 \mathrm{c}$ & $4.45 \mathrm{~b}$ & $0.35 \mathrm{c}$ & $0.37 \mathrm{c}$ & $0.42 \mathrm{c}$ & 0.43 \\
$\mathrm{M}_{2}$ & $4.06 \mathrm{~b}$ & $4.28 \mathrm{~b}$ & $4.38 \mathrm{~b}$ & $4.57 \mathrm{a}$ & $0.38 \mathrm{~b}$ & $0.41 \mathrm{~b}$ & $0.44 \mathrm{~b}$ & 0.44 \\
$\mathrm{M}_{3}$ & $4.27 \mathrm{a}$ & $4.39 \mathrm{a}$ & $4.50 \mathrm{a}$ & $4.61 \mathrm{a}$ & $0.42 \mathrm{a}$ & $0.45 \mathrm{a}$ & $0.46 \mathrm{a}$ & 0.44 \\
Ethephon conc. & & & & & & & \\
$\mathrm{T}_{1}$ & 4.06 & $4.111 \mathrm{c}$ & $4.24 \mathrm{~d}$ & $4.36 \mathrm{c}$ & 0.38 & 0.39 & $0.41 \mathrm{c}$ & 0.43 \\
$\mathrm{~T}_{2}$ & 4.06 & $4.32 \mathrm{~b}$ & $4.32 \mathrm{c}$ & $4.58 \mathrm{~b}$ & 0.37 & 0.41 & $0.43 \mathrm{~b}$ & 0.44 \\
$\mathrm{~T}_{3}$ & 4.08 & $4.36 \mathrm{ab}$ & $4.42 \mathrm{~b}$ & $4.58 \mathrm{~b}$ & 0.39 & 0.42 & $0.46 \mathrm{a}$ & 0.45 \\
$\mathrm{~T}_{4}$ & 4.02 & $4.37 \mathrm{a}$ & $4.46 \mathrm{a}$ & $4.65 \mathrm{a}$ & 0.39 & 0.43 & $0.46 \mathrm{a}$ & 0.46 \\
\hline $\mathrm{CV}(\%)$ & 3.55 & 2.69 & 3.84 & 4.06 & 2.78 & 2.52 & 3.45 & 4.13 \\
\hline
\end{tabular}

Means within a column having different letters are significantly different at $5 \%$ level by DMRT, $M_{1}=$ Mature green stage, $M_{2}=$ Breaker stage, $M_{3}=$ Half ripen stage, $\mathrm{T}_{1}=$ Control (distilled water), $\mathrm{T}_{2}=500 \mathrm{ppm}, \mathrm{T}_{3}=750 \mathrm{ppm}, \mathrm{T}_{6}=1000 \mathrm{ppm} ; \mathrm{D}=\mathrm{Day}$.

\section{TSS content of tomato pulp}

TSS content of tomato pulp varied significantly in fruits of different maturity (Table 8 ). Half ripen tomato contained the highest quantity of TSS (4.27\%) while it was the lowest (3.83\%) in mature green tomatoes at harvest. For all maturity stages, TSS increased gradually with the advancement of ripening process. This is in consonance with the results of Moneruzzaman et al. (2008b) and Helyes et al. (2006). Ethephon levels were also found to have significant effects on changes in TSS content of tomato juice at 3, 6, and 9 days of storage. The 
ethephon level of $1000 \mathrm{ppm}$ gave the maximum TSS content at 3,6 and 9 day of storage, followed by $750 \mathrm{ppm}$ ethephon in all days of storage. This corroborates the results of Bal and Kok (2007) who found the highest value of TSS at 1000 ppm ethephon compared to $500 \mathrm{ppm}$ ethephon. At 3 day of storage there was no significant difference between 750 and $1000 \mathrm{ppm}$ with regard to TSS content.

Table 9. Combined effect maturity stages and ethephon on TSS content of tomato (cv. BARI Tomato-14 ) fruits during storage.

\begin{tabular}{|c|c|c|c|c|c|}
\hline \multicolumn{6}{|c|}{ Duration of storage } \\
\hline \multicolumn{2}{|c|}{ Treatment } & \multirow[b]{2}{*}{ OD } & \multirow[b]{2}{*}{$3 \mathrm{D}$} & \multirow[b]{2}{*}{$6 \mathrm{D}$} & \multirow[b]{2}{*}{ 9D } \\
\hline $\begin{array}{l}\text { Maturity } \\
\text { stage }\end{array}$ & $\begin{array}{l}\text { Ethephon } \\
\text { conc. }\end{array}$ & & & & \\
\hline \multirow{4}{*}{$\mathrm{M}_{1}$} & $\mathrm{~T}_{1}$ & 3.82 & $3.92 \mathrm{~g}$ & $4.11 \mathrm{~g}$ & $4.26 f$ \\
\hline & $\mathrm{T}_{2}$ & 3.85 & $4.25 \mathrm{e}$ & $4.18 \mathrm{f}$ & 4.46de \\
\hline & $\mathrm{T}_{3}$ & 3.85 & 4.31de & $4.25 \mathrm{e}$ & $4.49 \mathrm{~d}$ \\
\hline & $\mathrm{T}_{4}$ & 3.80 & $4.32 \mathrm{de}$ & $4.28 \mathrm{e}$ & $4.59 \mathrm{c}$ \\
\hline \multirow{4}{*}{$\mathrm{M}_{2}$} & $\mathrm{~T}_{1}$ & 4.07 & $4.12 \mathrm{f}$ & $4.23 \mathrm{e}$ & $4.42 \mathrm{e}$ \\
\hline & $\mathrm{T}_{2}$ & 4.05 & $4.31 \mathrm{de}$ & $4.35 \mathrm{~d}$ & $4.61 b c$ \\
\hline & $\mathrm{T}_{3}$ & 4.09 & $4.35 \mathrm{bcd}$ & $4.44 \mathrm{c}$ & $4.61 b c$ \\
\hline & $\mathrm{T}_{4}$ & 4.03 & $4.34 \mathrm{~cd}$ & $4.51 b$ & $4.65 b c$ \\
\hline \multirow{4}{*}{$\mathrm{M}_{3}$} & $\mathrm{~T}_{1}$ & 4.28 & 4.30de & $4.38 \mathrm{~d}$ & $4.40 \mathrm{e}$ \\
\hline & $\mathrm{T}_{2}$ & 4.05 & $4.40 \mathrm{abc}$ & $4.43 c$ & 4.68ab \\
\hline & $\mathrm{T}_{3}$ & 4.28 & 4.42ab & $4.57 \mathrm{a}$ & $4.65 \mathrm{abc}$ \\
\hline & $\mathrm{T}_{4}$ & 4.22 & $4.46 \mathrm{a}$ & $4.61 \mathrm{a}$ & $4.72 \mathrm{a}$ \\
\hline CV $(\%)$ & & 3.55 & 2.69 & 3.84 & 4.06 \\
\hline
\end{tabular}

Means within a column having different letters are significantly different at $5 \%$ level by DMRT, $\mathrm{M}_{1}=$ Mature green, $\mathrm{M}_{2}=$ Breaker stage, $\mathrm{M}_{3}=$ Half ripen stage, $\mathrm{T}_{1}=$ Control (distilled water), $\mathrm{T}_{2}=500 \mathrm{ppm}, \mathrm{T}_{3}=750 \mathrm{ppm}, \mathrm{T}_{6}=1000 \mathrm{ppm} ; \mathrm{D}=$ Day.

The TSS content was also found to be significantly influenced by the combined effect of maturity stages and ethephon levels at 3,6 and 9 days of storage (Table 9). At 3, 6 and 9 days of storage 500, 750 and $1000 \mathrm{ppm}$ ethephon gave the highest total soluble solid (TSS) compared to control. In green mature tomatoes there was no significant difference between 750 and $1000 \mathrm{ppm}$ ethephon with regard to TSS\%. In breaker stage 500, 750 and 1000 ppm ethephon maintained a lead over control but they give identical results in respect of TSS content at 3 and 6 days of storage. Again in full ripen stage 750 and 1000 and 2000 ppm ethephon produced statistically similar TSS \% at all days of storage.

\section{Titrable acidity content of tomato pulp}

The total titrable acidity in tomato pulp varied significantly in fruits of different maturity (Table 8 ). The half ripen tomato pulp gave the maximum titrable acidity at harvest and also during entire period of storage except 9 day of storage and contained the highest quantity of titrable acidity $(0.46 \%)$ at 6 day of storage followed by breaker stage tomatoes. The mature green tomatoes produced lower titrable acidity in fresh and 3 and 6 day of storage. This is in consonance with the 
results of Moneruzzaman et al. (2008b). However, there was no significant difference among green mature stage, breaker stage and half ripen stage in respect of titrable acidity at 9 day of storage. The ethephon effect on titrable acidity was significant at 6 day of storage. The ethephon level of 750 and $1000 \mathrm{ppm}$ gave the highest titrable acidity $(0.46 \%)$ at 6 day of storage but no significant effect was found at 3 and 9 day of storage. The interaction effect was insignificant.

Table 10. Estimated residue level of ethrel (ethephon) (ppm) in treated tomato (var. BARI Tomato-14).

\begin{tabular}{l|c|c}
\hline \multirow{2}{*}{ Ethephon level } & \multicolumn{2}{|c}{ Days after application } \\
\cline { 2 - 3 } & 3 day & 5 day \\
\hline $\mathrm{T}_{1}$ & 0.00 & 0.00 \\
$\mathrm{~T}_{2}$ & 0.520 & 0.471 \\
$\mathrm{~T}_{3}$ & 0.658 & 0.569 \\
$\mathrm{~T}_{4}$ & 0.881 & 0.802 \\
$\mathrm{~T}_{5} *$ & 1.468 & 1.234 \\
\hline
\end{tabular}

$\mathrm{T}_{1}=$ Contro (distilled water), $\mathrm{T}_{2}=500 \mathrm{ppm}, \mathrm{T}_{3}=750 \mathrm{ppm}, \mathrm{T}_{4}=1000 \mathrm{ppm}, * \mathrm{~T}_{5}=2000$ ppm (extra treament), Existing CXL (codex residue level)-2 $\mathrm{mg} / \mathrm{kg}$ (2 ppm) ethephone (Anon., 2001).

\section{Residue Level of ethephon}

Table 10 revealed that the tomato fruits treated with $2000 \mathrm{ppm}$ ethrel solution showed the maximum residue value at 3 and 5 day of storage. The residue level in treated tomatoes decreased at 5 days compared to 3 days. It might be the reason that ethephon was a volatile compound. This was in perfect agreement with Beitz et al. (1977). The resdue level of ethrel in tomato fruits treated with 500-2000 ppm ethephon was less than the recommended residue level of ethephon (2 mg/kg) (Anon., 2001).

Based on the results and discussion it might be concluded that tomato fruits should be harvested at mature green stage and breaker stage for distant marketing for ethephon application @ 750 ppm for tomato ripening. The ethephon treated fruits should be consumed after 3 or 4 days of ethephon application.

\section{References}

Abeles, F. B., P. W. Morgan and M. Saltveit. 1992. Ethylene in Plant Biology. $2^{\text {nd }}$ Ed., Academic Press New York. P. 156.

Anju-kumari, M. 1., S. P. S. Bhardwaj and A. Kumari. 1993. Influence of stage of harvest on shelf life and quality of tomato. Hort. J. 6: 89-92.

Anonymous. 2001. European Community Position for the $33^{\text {rd }}$ Session of the Codex Committee on Pesticide Residues. April, 2001. The Hague.

Anonymous. 2010. Delicious fruit quality can be affected by ethephon or retain. Post harvest information network. Washington State University. http://postharvest.tfree.wsu.edu /pages/ PC99A.

Bal, E. and D. Kok. 2007. The effects of glycerine added ethephon treatments on fruit characteristics of Aclimidia deliciosa cv. Hayward. Bulgarian J. Agril. Sci. 13: 291-300. 
BARC (Bangladesh Agricultural Research Council). 2012. Research Management Information System. http:/180. 211. 164. 225/rmis /index. php? $\mathrm{t}=$ detail info\&linkid=1277.

BBS (Bangladesh Bureau of Statistics). 2011. Statistical Year Book of Bangladesh, Bangladesh Bureau of Statistics, Bangladesh. P. 136.

Beitz, H, U. Banasiak and U. Bergner. 1977. Behavior of ethephon residues on tomatoes. Part 1. Green house tomatoes. www. nebi.nlm.mh.gov./pubmed/703819.

Bui Q. Q., 2007. Ethephon and Jackfruit, Palo Alto, California. 231pp

Cantwell, M. 1994. Optimum procedures for ripening tomatoes. In: Management of Fruit ripening, Post harvest Horticulture. Series No. 9, Post harvesr Outreach Program, Dept. of Pomology, Univ. of California, Davis (UCDAVIS). Pp. 27-28.

Dhall R.K., P. Singh. 2013. Effect of ethephon and ethylene gas on ripening and quality of Tomato (Solanum lycopersicum L.) during cold storage. J. Nutr. Food Sci. 3: 244.

Helyes, L., J. Dimeny, Z. Pek and A. Lugasi. 2006. Effect of maturity stage on content, colour and quality of tomato (Lycopersican lycopersicum (L.) (Karsten) fruit. Int. J. Hort. Sci. 12 (1): 41-44.

Matsumoto, S., T. Obara and B. S. Luh. 1983. Changes in chemical constituents of Kiwi fruit during post-harvest ripening. J. Food Sci. 48: 607-611.

Mitcham, E.J., Gross, K.C., J-Ng, T., 1989. Tomato fruit cell synthesis during development and senescence. Plant Physiol. 89, 477-481.

Moneruzzaman, K. M., A. B. M. S. Hossain, W. Sani and M. Safiuddin. 2008a. Effect of stages of maturity and ripening conditions on the physical characteristics of tomato. Ame. J. Bioch. and Biotech. 4(4): 329-335.

Moneruzzaman, K. M., A. B. M. S. Hossain, W. Sani and M. Safiuddin. 2008b. Effect of stages of maturity and ripening conditions on the biochemical characteristics of tomato. Ame. J. Bioch. and Biotech. 4(4): 336-344.

Moura, M. A., S.R. Zanin and F.L. Finger. 1997. Influence of ethephon and a surfactant on ripening of harvested tomato fruit. HortScience. 32: 3478.

Olympio, V.M. and J.C. Norman. 2000. Influence of pre-post harvest application of ethephone (2 chloroethyl phosphonic acid) on tomatoes. http:// hortsci.ashspublications.org/ content/ 32/3/ 478.4.abstract

Quoc, L.P.T., C.P. Dat, A.T. Hang., T.H. Mi and L.T.T. Nga. 2012. Regarding the influence of ethephon on the ripe acerola (Malpighia glabra L.). Cercetări Agronomice în Moldova. 4: 152.

Rahman, M. A., M. S. Ahmed, A. Begum and M. W. Akon. 2012. Determination and quantification of left over residues of ethephon in tomato, banana and mango. Annual Report for 2011-2012. Enomology Division, Bangladesh Agricultural Research Institue, Gazipur. Pp. 192-197.

Ranganna, S. 1986. Handbook of Analysis and Quality control for Fruit and Vegetable products. Tata McGraw Hill Pub. Co. Ltd., New Delhi, India. Pp. 1143.

Thanh Hai, V. U., P. T. Huong, P. Sruamsiri, M. Hegele and J. N. Winsche. 2009. Effect of ethrel postharvest application on ripening of 'Tron' and 'Hoi' mangoes (Mangifera indica L.). Conf. on Int. Res. on Food Security, Natural Resource management and Rural Development, Univ. Of Humburg, Oct. 6-8, 2009. P. 75-76.

Wills, R. B. H. and V. V. V. Ku. 2002. Use of 1-MCP to extend the tomato ripen of green tomatoes and post harvest life of ripe tomatoes. Postharv. Biol. Technol. 26: 85-90. 